\title{
Performance risk analysis on mutual funds versus stock exchanges in young financial markets
}

\section{Luminita Nicolescu}

Department of International Economic Relations,

Bucharest University of Economic Studies,

Romania

luminicolescu@yahoo.com

\section{Florentin Gabriel Tudorache}

Economic and International Affairs Doctoral School,

Bucharest University of Economic Studies,

Romania

gabriel tud@yahoo.com

\author{
Armenia Androniceanu \\ Department of Administration and Public Management, \\ Bucharest University of Economic Studies, \\ Romania \\ Research Department, University of Social Sciences, Lodz, \\ Poland \\ armenia.androniceanu@man.ase.ro
}

Abstract. Financial markets play an important role in the economies of the world as they are supporting economic development. The present paper focuses on the young financial markets of Central and Eastern Europe with the focus on three selected cases: Romania, Slovakia and Hungary. In these countries, the capital markets are studied through the assessment of performances and risks associated with mutual funds by comparison with stock exchanges. Statistical documentation and statistical empirical research were used in order to compare mutual funds' evolution with the stock markets' evolution. The period of analysis also comprised the global financial and economic crisis, with obvious consequences on the results of the analysis. Among the main findings of the study are: mutual funds performed better (both in terms of returns and risks) than stock exchanges in the periods of economic turmoil; a movement from investing in highrisk assets (equity) towards investing in low-risk assets (bonds and monetary assets) takes place in the periods of economic distress; there were more similarities than differences in the evolutions of mutual funds and stock exchanges in these three countries, illustrating common characteristics at the

Received September, 2019

1st Revision: December, 2019

Accepted: February, 2020

DOI: $10.14254 / 2071$ 8330.2020/13-1/18 
regional level. The study concludes that mutual funds outperform stock markets, especially during economically difficult periods. This can be taken into consideration by fund administrators when deciding on their assets portfolio and when marketing their funds to investors.

Keywords: mutual funds, Central and Eastern Europe, financial markets, Romania, Slovakia, Hungary.

JEL Classification: G15, G23, F30, F65

\section{INTRODUCTION}

Financial and capital markets in Central and Eastern Europe are young markets that have (re)developed after 1990, together with the political changes that took place in the region. Studies conducted in the region focused on different aspects related to financial markets such as the role of financial markets in the succession of economic cycles (Cevik et al., 2016), the interaction between monetary and fiscal policies (Androniceanu et al., 2019), testing of the local currencies for regional development (Cepel et al., 2019), market integration impact on real economy (Bekaert \& Harvey, 2003; Hilkevics, Hilkevica, 2017) and others. Another category of studies looked at capital markets from the perspective of the level of capitalization in Central and Eastern Europe (Albu et al., 2014), integration of capital markets (Horobeț \& Belașcu, 2015), financial contagion and propagation of financial shocks (Barunik \& Vacha, 2013) or looked at these markets from the perspective of financial possibilities for firms (Mura \& Buleca, 2012; Hudáková et al., 2017; Kinnunen et al. 2019). Some studies looked at stock markets in the region and few at mutual funds, but there is a scarcity of studies comparing mutual funds' markets with stock exchange markets, as the present study does. The paper is organized as follows: the first section focuses on the literature that looked at stock markets and mutual funds in the region and mainly in the three countries in question (Romania, Slovakia and Hungary), the second section describes in detail the methodology used, the third section presents the main results of the study and the last section includes the conclusions of the study.

\section{LITERATURE REVIEW}

Though financing, financial crisis, financial development, and financial literacy have been the most prominent topics in the field of finance over the last 2-3 years (Garcia-Machado, 2018), one of the main themes in the literature looking at mutual funds and stock exchanges relates to the performance analysis. There are studies that demonstrate how past performances influence the present capital flows into funds (Sirri \& Tufano, 1998; Chen \& Qin, 2015; Filip, 2017a, 2017b; Filip, 2018; Tudorache et al., 2015; Tung, 2018; Chovancova et al., 2019) illustrating a strong fund-flow relationship. The fact that capital chases past performance, makes the study of performance, measured as both returns and risks, an important aspect to be looked at in order to predict future capital flows. Stotz (2020) for instance, shows how in case to stock markets the equity curve can be used as a predictive instrument for future stock returns, therefore, being suitable to be used in the management of stock exposure in the investment decision. Frahm and Huber (2019) found in their study that most of the mutual funds were able to beat the market and they even proposed a new performance measure called outperformance probability. In turn, Mesagan et al., (2019) analyzed the growth effects of financial market instruments in Ghana between 1991 and 201, using the Autoregressive Distributed Lags (ARDL) bounds testing approach to evaluate data on real GDP per 
capita, monetary policy rate, treasury bill rate, stocks traded, bank credits, stock turnover, market capitalization, foreign direct investment, and gross investment.

At regional level, there are a number of studies that approached the stock exchanges from Central and Eastern Europe from different perspectives: their evolution and performances (Horobeț \& Belașcu, 2015; Vychytilova, 2018; Darabos, 2016; Gavurova et al., 2017); the relationship between the stock exchange and the degree of economic development in the region (Prats \& Sandoval, 2016; Nadirov et al., 2017); the stock exchange role in economic shocks propagation (Deltuvaite, 2016) or the impact of the stock exchange volatilies on the sentiment indexes (Albu et al., 2014; Bilan, Y. et al., 2017), the role of management (Ključnikov, et al., 2019; Androniceanu et al., 2020) and business environment (Ajaz Khan et al., 2019) in financing, capital movement (Tvaronavičiené, 2019; Chehabeddine \& Tvaronavičiene், 2020).

The studies that looked at the mutual funds in Central and Eastern Europe, focused on aspects such as the performance of mutual funds (Filip, 2017a; Filip 2017b), the identification and the analysis of the factors affecting the development of mutual funds in the region (Bajus \& Stasova, 2015; Lemeshko \& Rejnus, 2015). As far as the returns of mutual funds are concerned Filip (2017b) noticed that they present smaller fluctuations in comparison with the stock indexes in the Czech Republic, Hungary and Poland in the period 2000-2015. The analysis of the influencing factors of the mutual funds industry reconfirm the macroeconomic factors (GDP, governance, financial markets development) and the microeconomic factors (propensity towards risks, cultural openness to capital trade) as determinants in the industry's evolution (Lemeshko \& Rejnus, 2015).

Studies that analyse at country level capital markets, stock exchanges and mutual funds are less numerous. Some of these studies are in Poland (Filip, 2018; Swiecka et al., 2020; Raišienè et al., 2019) and in the Czech Republic (Sindelar \& Budinsky, 2019). There were also identified some studies conducted in the countries of interest of the present research.

In Romania, Jaba et al. (2013) studying the capital market, illustrated how the public information about the financial situation of companies listed at the Bucharest Stock Exchange influenced the market value of shares. The assumption that the announcement of positive book results will determine a better share price has not been verified for all types of financial information available. Dragotă et al. (2016) conducted an analysis of the socio-economic factors that influence the development of the mutual funds in Romania. Also, Tudorache et al. (2015) looked at the evolution of mutual funds in Romania from the returns and risks' perspectives (Simionescu, 2016).

In Slovakia, Fidrmuc et al. (2013) explain the high level of contagion that affected the capital market due to the high level of financial integration with other European markets from Austria, Italy, Belgium. Bukowski (2014) characterizes the Bratislava Stock Exchange as the smallest market in the Euro area according to the market capitalization as a percentage of GDP. Brokesova et al. (2017) illustrated the positive relationship between the financial knowledge of individuals (Poór et al., 2018) and the participation to private schemes of pensions (as a possible incentivising factor for the development of mutual funds).

In Hungary, Filip (2014) tried to identify the extent to which the performance of mutual funds is influenced by the elimination of non-surviving funds when evaluating the performance. Also, Filip (2011) analysed the performance persistence of the equity funds and its influencing role in Hungary. The scarcity of the studies that focus on the comparison of mutual funds to the stock exchanges in the considered countries, justifies the proposed analysis that comes to complete the existing literature. 


\section{METHODOLOGY}

The objective of the present research is to conduct the performance - risk analysis for mutual funds by comparison with the stock exchanges in selected young financial markets from Central and Eastern Europe, namely Romania, Slovakia and Hungary. There are two methodological approaches in this research: a) the first one is based on statistical documentation about the mutual fund markets and the stock exchanges in the selected countries and b) the second is based on an empirical research conducted through descriptive statistics in relationship to mutual fund markets and stock exchanges in the selected markets. The statistical documentation looks at the time evolution of mutual funds (via total net assets, number of funds and net sales) and the time evolution of stock exchanges (via stock exchange indexes) in periods considered by our research (depending on the availability of data). Tables 1 and 2 present the evolution of mutual funds in the three countries as a total number of funds and on different mutual funds' types.

Table 1

Mutual funds in Romania, Slovakia and Hungary, 2003-2019

\begin{tabular}{|c|c|c|c|}
\hline Years/Countries & Romania & Slovakia & Hungary \\
\hline 2003 & 20 & 37 & 96 \\
\hline 2004 & 19 & 40 & 91 \\
\hline 2005 & 23 & 43 & 161 \\
\hline 2006 & 32 & 43 & 212 \\
\hline 2007 & 41 & 54 & 270 \\
\hline 2008 & 52 & 56 & 264 \\
\hline 2009 & 51 & 54 & 276 \\
\hline 2010 & 56 & 58 & 152 \\
\hline 2011 & 105 & 63 & 361 \\
\hline 2012 & 62 & 73 & 369 \\
\hline 2013 & 64 & 73 & 307 \\
\hline 2014 & 72 & 87 & 316 \\
\hline 2015 & 74 & 88 & 306 \\
\hline 2016 & 75 & 87 & 306 \\
\hline 2017 & 74 & 87 & 298 \\
\hline 2018 & 78 & 86 & 290 \\
\hline
\end{tabular}

Source: Investment Company Institute, 2019

The empirical analysis that is based on the descriptive statistical analysis has the purpose to describe the characteristics of time series data (Urdan, 2011), in our case to perform a return - risk analysis for mutual funds and stock exchanges in the analyzed period.

The data collected about the mutual funds included unitary value of the net assets of the fund. Based on these data, the returns were computed using a classical formula (Brooks, 2002, p. 8; Tsay, 2010, p. 5):

$$
R_{1 i, t}=\ln \frac{\operatorname{VUAN}_{i, t}}{\operatorname{VUAN}_{i, t-1}}=\ln \left(V U A N_{i, t}\right)-\ln \left(\operatorname{VUAN}_{i, t-1}\right)
$$

where VUAN $\mathrm{i}_{\mathrm{i} . \mathrm{t}}$ and VUAN $\mathrm{Vit-1}_{1}$ depict the unitary value of the net assets of fund ,i” in month „t "and „t$1 "$. 
Table 2

Types of mutual funds in Romania, Slovakia and Hungary, 2007-2019

\begin{tabular}{|c|c|c|c|c|c|c|c|c|c|c|c|c|c|c|}
\hline & Years & 2007 & 2008 & 2009 & 2010 & 2011 & 2012 & 2013 & 2014 & 2015 & 2016 & 2017 & 2018 & 2019 \\
\hline \multirow[t]{7}{*}{ ROMANIA } & Total & 41 & 52 & 51 & 57 & 63 & 64 & 64 & 70 & 74 & 75 & 74 & 78 & 78 \\
\hline & $\begin{array}{l}\text { Equity } \\
\text { funds }\end{array}$ & 14 & 11 & 9 & 14 & 16 & 16 & 17 & 17 & 17 & 19 & 19 & 14 & 14 \\
\hline & $\begin{array}{l}\text { Bond } \\
\text { funds }\end{array}$ & 8 & 10 & 9 & 5 & 7 & 7 & 18 & 18 & 17 & 15 & 15 & 13 & 13 \\
\hline & $\begin{array}{l}\text { Mixed } \\
\text { funds }\end{array}$ & 15 & 18 & 17 & 23 & 24 & 23 & 22 & 25 & 29 & 27 & 27 & 27 & 27 \\
\hline & $\begin{array}{c}\text { Monetary } \\
\text { funds }\end{array}$ & 3 & 5 & 5 & 7 & 8 & 1 & 1 & 1 & 1 & 1 & 1 & 0 & 0 \\
\hline & $\begin{array}{l}\text { Other } \\
\text { funds }\end{array}$ & 1 & 8 & 11 & 7 & 7 & 16 & 6 & 9 & 10 & 13 & 12 & 22 & 22 \\
\hline & $\begin{array}{l}\text { Other } \\
\text { types of } \\
\text { funds }\end{array}$ & $\mathrm{N} / \mathrm{A}$ & $\mathrm{N} / \mathrm{A}$ & $\mathrm{N} / \mathrm{A}$ & 1 & 1 & 1 & $\mathrm{~N} / \mathrm{A}$ & $\mathrm{N} / \mathrm{A}$ & $\mathrm{N} / \mathrm{A}$ & $\mathrm{N} / \mathrm{A}$ & $\mathrm{N} / \mathrm{A}$ & 3 & 3 \\
\hline \multirow[t]{7}{*}{ SLOVAKIA } & Total & 54 & 56 & 54 & 58 & 63 & 58 & 54 & 67 & 88 & 87 & 87 & 86 & 90 \\
\hline & $\begin{array}{l}\text { Equity } \\
\text { funds }\end{array}$ & $\mathrm{N} / \mathrm{A}$ & $\mathrm{N} / \mathrm{A}$ & $\mathrm{N} / \mathrm{A}$ & $\mathrm{N} / \mathrm{A}$ & $\mathrm{N} / \mathrm{A}$ & $\mathrm{N} / \mathrm{A}$ & $\mathrm{N} / \mathrm{A}$ & $\mathrm{N} / \mathrm{A}$ & 9 & 9 & 10 & 8 & 10 \\
\hline & $\begin{array}{l}\text { Bond } \\
\text { funds }\end{array}$ & $\mathrm{N} / \mathrm{A}$ & $\mathrm{N} / \mathrm{A}$ & $\mathrm{N} / \mathrm{A}$ & $\mathrm{N} / \mathrm{A}$ & $\mathrm{N} / \mathrm{A}$ & $\mathrm{N} / \mathrm{A}$ & $\mathrm{N} / \mathrm{A}$ & $\mathrm{N} / \mathrm{A}$ & 27 & 26 & 25 & 24 & 24 \\
\hline & $\begin{array}{l}\text { Mixed } \\
\text { funds }\end{array}$ & $\mathrm{N} / \mathrm{A}$ & $\mathrm{N} / \mathrm{A}$ & $\mathrm{N} / \mathrm{A}$ & $\mathrm{N} / \mathrm{A}$ & $\mathrm{N} / \mathrm{A}$ & $\mathrm{N} / \mathrm{A}$ & $\mathrm{N} / \mathrm{A}$ & $\mathrm{N} / \mathrm{A}$ & 42 & 45 & 43 & 47 & 49 \\
\hline & $\begin{array}{c}\text { Monetary } \\
\text { funds }\end{array}$ & $\mathrm{N} / \mathrm{A}$ & $\mathrm{N} / \mathrm{A}$ & $\mathrm{N} / \mathrm{A}$ & $\mathrm{N} / \mathrm{A}$ & $\mathrm{N} / \mathrm{A}$ & $\mathrm{N} / \mathrm{A}$ & $\mathrm{N} / \mathrm{A}$ & $\mathrm{N} / \mathrm{A}$ & 4 & 3 & 2 & 0 & 0 \\
\hline & $\begin{array}{l}\text { Other } \\
\text { funds }\end{array}$ & $\mathrm{N} / \mathrm{A}$ & $\mathrm{N} / \mathrm{A}$ & $\mathrm{N} / \mathrm{A}$ & $\mathrm{N} / \mathrm{A}$ & $\mathrm{N} / \mathrm{A}$ & $\mathrm{N} / \mathrm{A}$ & $\mathrm{N} / \mathrm{A}$ & $\mathrm{N} / \mathrm{A}$ & 0 & 0 & 0 & 0 & 0 \\
\hline & $\begin{array}{l}\text { Other } \\
\text { types of } \\
\text { funds }\end{array}$ & $\mathrm{N} / \mathrm{A}$ & $\mathrm{N} / \mathrm{A}$ & $\mathrm{N} / \mathrm{A}$ & $\mathrm{N} / \mathrm{A}$ & $\mathrm{N} / \mathrm{A}$ & $\mathrm{N} / \mathrm{A}$ & $\mathrm{N} / \mathrm{A}$ & $\mathrm{N} / \mathrm{A}$ & 10 & 8 & 11 & 10 & 10 \\
\hline \multirow[t]{7}{*}{ HUNGARY } & Total & 212 & 270 & 264 & 276 & 152 & 167 & 182 & 189 & 316 & 306 & 306 & 298 & 290 \\
\hline & $\begin{array}{l}\text { Equity } \\
\text { funds }\end{array}$ & $\mathrm{N} / \mathrm{A}$ & $\mathrm{N} / \mathrm{A}$ & $\mathrm{N} / \mathrm{A}$ & $\mathrm{N} / \mathrm{A}$ & $\mathrm{N} / \mathrm{A}$ & $\mathrm{N} / \mathrm{A}$ & $\mathrm{N} / \mathrm{A}$ & $\mathrm{N} / \mathrm{A}$ & 52 & 52 & 64 & 66 & 67 \\
\hline & $\begin{array}{l}\text { Bond } \\
\text { funds }\end{array}$ & $\mathrm{N} / \mathrm{A}$ & $\mathrm{N} / \mathrm{A}$ & $\mathrm{N} / \mathrm{A}$ & $\mathrm{N} / \mathrm{A}$ & $\mathrm{N} / \mathrm{A}$ & $\mathrm{N} / \mathrm{A}$ & $\mathrm{N} / \mathrm{A}$ & $\mathrm{N} / \mathrm{A}$ & 52 & 49 & 44 & 46 & 60 \\
\hline & $\begin{array}{l}\text { Mixed } \\
\text { funds }\end{array}$ & $\mathrm{N} / \mathrm{A}$ & $\mathrm{N} / \mathrm{A}$ & $\mathrm{N} / \mathrm{A}$ & $\mathrm{N} / \mathrm{A}$ & $\mathrm{N} / \mathrm{A}$ & $\mathrm{N} / \mathrm{A}$ & $\mathrm{N} / \mathrm{A}$ & $\mathrm{N} / \mathrm{A}$ & 42 & 47 & 44 & 44 & 40 \\
\hline & $\begin{array}{l}\text { Monetary } \\
\text { funds }\end{array}$ & $\mathrm{N} / \mathrm{A}$ & $\mathrm{N} / \mathrm{A}$ & $\mathrm{N} / \mathrm{A}$ & $\mathrm{N} / \mathrm{A}$ & $\mathrm{N} / \mathrm{A}$ & $\mathrm{N} / \mathrm{A}$ & $\mathrm{N} / \mathrm{A}$ & $\mathrm{N} / \mathrm{A}$ & 46 & 44 & 38 & 35 & 13 \\
\hline & $\begin{array}{l}\text { Other } \\
\text { funds }\end{array}$ & $\mathrm{N} / \mathrm{A}$ & $\mathrm{N} / \mathrm{A}$ & $\mathrm{N} / \mathrm{A}$ & $\mathrm{N} / \mathrm{A}$ & $\mathrm{N} / \mathrm{A}$ & $\mathrm{N} / \mathrm{A}$ & $\mathrm{N} / \mathrm{A}$ & $\mathrm{N} / \mathrm{A}$ & 65 & 82 & 92 & 93 & 96 \\
\hline & $\begin{array}{l}\text { Other } \\
\text { types of } \\
\text { funds }\end{array}$ & $\mathrm{N} / \mathrm{A}$ & $\mathrm{N} / \mathrm{A}$ & $\mathrm{N} / \mathrm{A}$ & $\mathrm{N} / \mathrm{A}$ & $\mathrm{N} / \mathrm{A}$ & $\mathrm{N} / \mathrm{A}$ & $\mathrm{N} / \mathrm{A}$ & $\mathrm{N} / \mathrm{A}$ & 91 & 78 & 71 & 73 & 85 \\
\hline
\end{tabular}

Note: Number of funds includes only the local mutual funds that administer local assets. RO $=$ Romania; SK $=$ Slovakia; HU = Hungary; Other types of funds include real estate funds, guarantee funds, etc.

Sources: European Foundation and Asset Management Association, 2019, International Statistical Release, 2012-2019; Authority for Financial Monitoring, 2012-2019

In order to characterize both performance and risks, it was used the monthly return indicator that is seen as a better statistical measure than prices, for risk modelling (Christoffersen, 2015, p. 7).

The mean returns as a central tendency indicator (Andrei \& Bourbonnais, 2017) is also known as the expected value (Rachev et al., 2007) and permits for the evaluation of the performance evolution in time and allows at the same time comparisons between the performances of the funds with the stock exchange indexes, between fund categories and between countries. Standard deviation of returns illustrates the 
spread of the individual values around the mean (Gravetter \& Wallnau, 2005, p. 94) and in case of financial data it reflects the risk associated with each studied category, allowing for comparisons between different fund categories and stock exchanges. However, there are authors that consider that the mean and the standard deviation do not characterize adequately the distribution of returns (DeRichard et al., 2015) and do not give sufficient information about performances and risks. Therefore, there is necessary to continue the analysis by looking at skewness and kurtosis coefficients. Skewness characterizes a distribution that is not symmetrical around the mean (Ruppert \& Matteson, 2015) and offers an image of the frequency with which returns are concentrated in one direction of the distribution or another (left or right) and has either positive or negative values. In the present study a negative skewness coefficient indicates a higher probability to encounter extreme negative values of the returns - high risks), while a positive skewness coefficient indicates a higher probability to encounter positive extreme values of returns - very good results). The kurtosis coefficient is a statistical measure that indicates if the values of the distribution are concentrated at the peak or at the bottom of the distribution and if the distribution has a higher or a lower peak in comparison with the normal distribution (DeRichard et al., 2015, p. 134).

In the present research the kurtosis coefficient indicates information about the probability to encounter extreme values of the returns and how many extreme values, through the grouping of the results in the tails of the distribution (Rachev et al., 2007; Rajnoha \& Lorincová, 2015). Generally speaking, it is considered that all investors base their decisions on the fact that the returns do not have a normal distribution (Tsay, 2010). In the present research we used the median of means, standard deviations, skewness and kurtosis coefficients of returns in order to conduct comparisons between groups.

For each country included in the study, the four moments of the returns distribution were analyzed for all mutual fund categories by comparison with the most representative stock exchange index in each country (BET - the index of the Bucharest Stock Exchange; SAX - the index for Bratislava Stock Exchange and the BUX - the index for Budapest Stock Exchange). The five categories of mutual funds included in the study are grouped according to EFAMA (European Fund and Asset Management Association) typology as: stock funds, mixed funds, other funds, bond funds and monetary funds, as the main fund categories operating in the three countries in the analyzed period. The monthly data (unitary value of the net assets of the fund and total net assets) were collected manually for each fund, in each country in the analyzed period. The data collected was used to compute the returns of the funds, that were further analyzed in terms of evolution in order to asses performance and risks associated to different categories of mutual funds. The analysis comprises monthly data collected from the databases of the associations of mutual fund administrators in each country (AAF in Romania. SASS in Slovakia and BAMOSZ in Hungary) and from the sites of the stock exchanges from each country, data collected for the period January 2007-December 2014. A total of 548 mutual funds in the three countries have been included in the final sample (subject to a minimum of 24 observations).

Table 3 presents the sample composed by the number of mutual funds that participated in the study. 
Sample of mutual funds analyzed in Romania, Slovakia and Hungary

\begin{tabular}{|l|c|c|c|c|}
\hline Type of funds/Countries & Romania & Slovakia & Hungary & TOTAL \\
\hline Initial funds included in the study & 105 & 177 & 510 & 792 \\
\hline TOTAL in sample (24 months condition) & 76 & 78 & 394 & $\mathbf{5 4 8}$ \\
\hline Equity funds & 15 & 7 & 126 & 365 \\
\hline Mixed funds & 27 & 18 & 45 & 148 \\
\hline Other funds & 19 & 34 & 125 & 178 \\
\hline Bond funds & 10 & 10 & 52 & 62 \\
\hline Monetary funds & 5 & 9 & 46 & 60 \\
\hline Total number of observations & $\mathbf{1 0 6 5 8}$ & $\mathbf{1 5 3 1 0}$ & $\mathbf{6 0 3 3 6}$ & $\mathbf{8 6 3 0 4}$ \\
\hline
\end{tabular}

Source: Authors from AAF, SASS, BAMOSZ

The stock indexed includes in the study are characterized as follows:

a) BET is the reference index for the capital market in Romania and it includes the evolution of the most traded companies on the regulated market of the Stock Exchange, except the financial investment companies (SIF). It was launched at 19 September 1997 and comprises between 10 and 15 companies. BET is a weighted price index, with free float capitalization, the maximum weight of a company being $20 \%$. Companies are selected to be included in the index based on liquidity, and from 2015 there are also considered for selection criteria aspects such as the issuer transparency, the quality of reporting and the quality of communication.

b) SAX is a major index of the capital market in Slovakia that monitors the performances of the companies that are listed at the Bratislava Stock Exchange. It is a weighted index with capitalization that compares the market capitalization of a selected set of shares with the capitalization of the same set of shares in a given reference day (BSSE, 1999-2018). SAX was launched on 14 September 1999 and it is measured in points that had the initial value of 100 at launch. It has a flexible structure that allows the participation of different most liquid companies in the calculation of the index and also the change in the number of companies included in the index according to their level of trading.

c) BUX is the official index of Budapest Stock Exchange that comprises the large and financially stable companies that are listed. The index is real time computed based on a the prices of a basket of shares. The index illustrates the average change of the prices of the shares with the highest value and returns.

The paper compares the returns of the mutual funds with the stock exchange indexes (BET, SAX and BUX) in order to identify which ones were more performed in the analyzed period and to establish if it is more advantageous for investors to acquire units at mutual funds or to invest at the stock exchange.

\section{EMPIRICAL RESULTS AND DISCUSSION}

The analysis of the activity of the stock exchanges (via stock indexes) and of the mutual funds (via total net assets, number of funds and net sales) in the three countries are presented in Figures 1 and 2 and Table 4. 


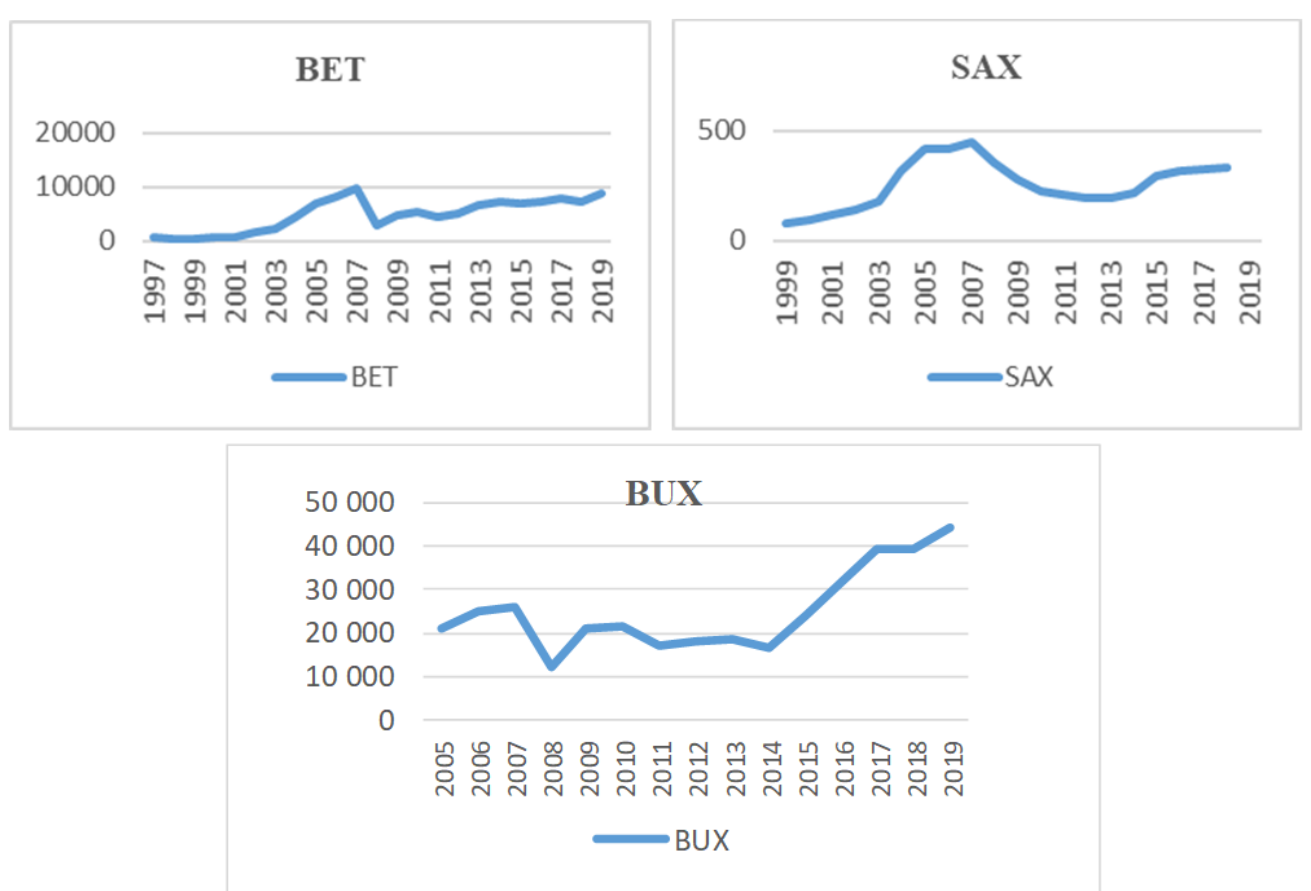

Figure 1. Evolution of stock exchange indexes in Romania (BET), Slovakia (SAX) and Hungary (BUX)

Table 4

Stock exchange indexes in Romania, Slovakia and Hungary (yearly)

\begin{tabular}{|c|c|c|c|}
\hline \multirow{2}{*}{ Years } & \multicolumn{3}{|c|}{ Stock exchange indexes } \\
\cline { 2 - 4 } & BET (Romania) & SAX (Slovakia) & BUX (Hungary) \\
\hline 1997 & 757 & - & - \\
\hline 1998 & 377 & - & - \\
\hline 1999 & 448 & 93.13 & - \\
\hline 2000 & 544 & 114.17 & - \\
\hline 2001 & 754 & 138.02 & - \\
\hline 2002 & 1659 & 177.19 & 21,012 \\
\hline 2003 & 2171 & 315.17 & 24,844 \\
\hline 2004 & 4376 & 420.26 & 26,235 \\
\hline 2005 & 6829 & 414.25 & 12,241 \\
\hline 2006 & 8050 & 444.66 & 21,227 \\
\hline 2007 & 9825 & 352.47 & 21,327 \\
\hline 2008 & 2901 & 281.23 & 16,974 \\
\hline 2009 & 4690 & 226.13 & 18,173 \\
\hline 2010 & 5268 & 213.07 & 18,564 \\
\hline 2011 & 4336 & 191.94 & 16,634 \\
\hline 2012 & 5149 & 195.36 & 23,920 \\
\hline 2013 & 6493 & 219.70 & 32,099 \\
\hline 2014 & 7083 & 296.81 & 39,377 \\
\hline 2015 & 7004 & 313.32 & 39,138 \\
\hline 2016 & 7085 & 324.08 & 44,314 \\
\hline 2017 & 7753 & 333.61 & - \\
\hline 2018 & 7383 & & - \\
\hline 2019 & 8814 & & - \\
\hline
\end{tabular}

Sources: Annual Reports 2013-2019 ASF - https://asfromania.ro/publicatii/; Bratislava Stock Exchange. Factbook (1999-2018), $\quad$ http://www.bsse.sk/bcpben/Statistics/Year/tabid/171/language/en-US/Default.aspx; https://markets.businessinsider.com/index/historical-prices/bux 
It can be noticed that Hungary has a larger and more developed capital market in comparison with Romania and Slovakia, from both the perspective of the total number of mutual funds (3-4 times more numerous in Hungary than in Romania and Slovakia), but also from the perspective of total net assets that were more than double in Hungary in comparison with Slovakia and Romania. Even though Romania is the country with the largest population and the largest economy, it has the smallest mutual fund market and the second stock exchange market among the three countries studied.

Total Net Assets (mil. \$)

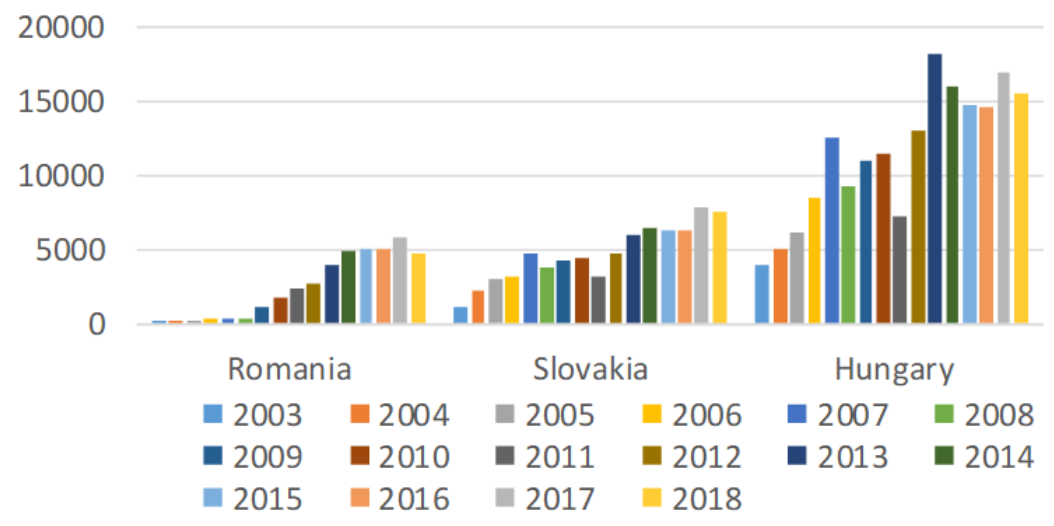

Number of mutual funds
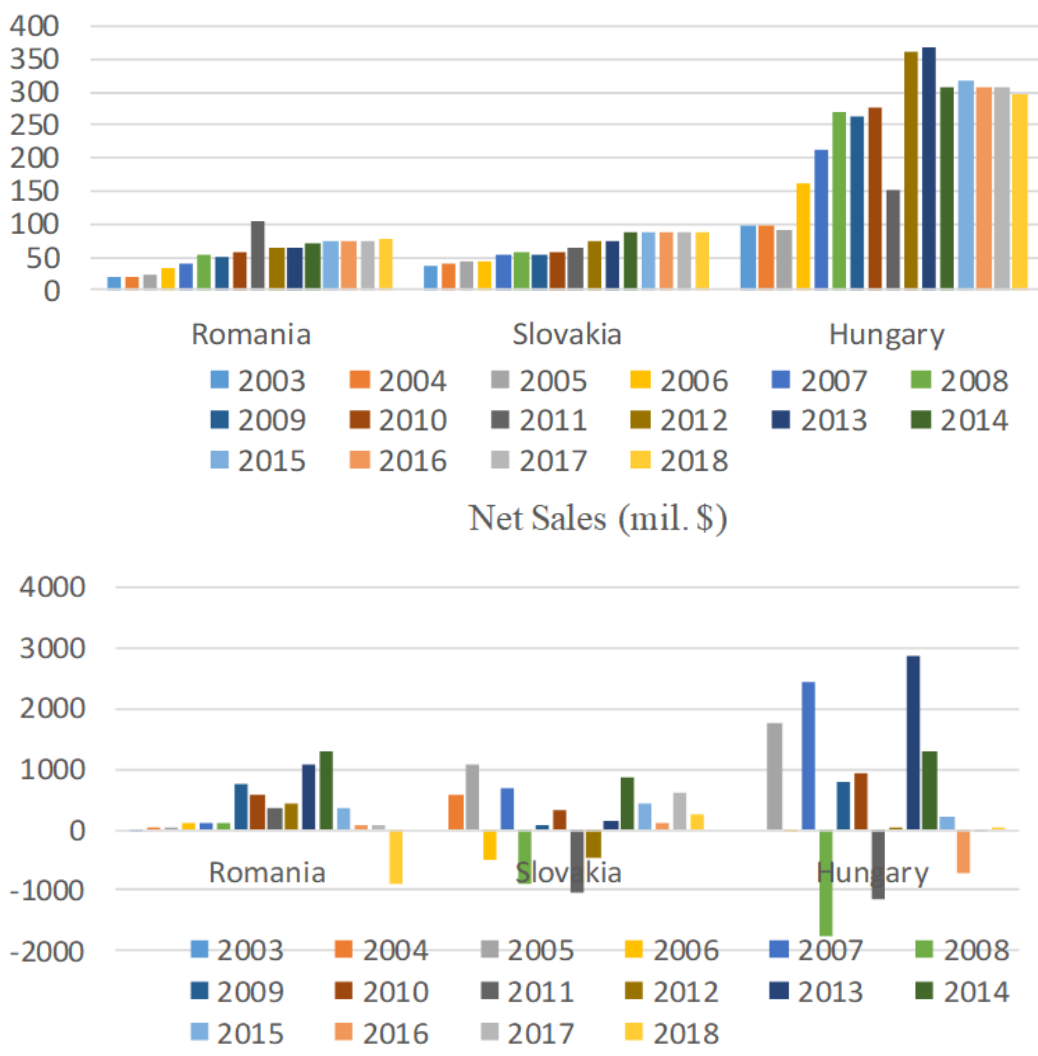

Figure 2. Evolution of mutual funds

Sources: http://www.icifactbook.org/data/, 2010, 2015, 2017, 2018 
The explanations for this state of facts can be related to: the low level of income of households, the low level of financial education of population in relationship to other countries in Europe and in Central and Eastern Europe (Batsaikhan \& Demertzis, 2018; Beckmann, 2013; Swiecka et al., 2020), a less developed system of private pensions (that usually encourage the development of mutual funds), the lack of investment culture and experience (Lusardi, 2019), the need for higher levels of knowledge based development.

Investors guide their investment decisions on the previous performances of the funds and of the stock exchange (Chen \& Qin, 2015; Li Ma, 2013; Phillips et al., 2016; Masood et al., 2019; Kaluge, 2019), therefore, the analysis of the returns for both investment funds and the stock exchange is needed to assess and compare their performances. Tables 5 and 6 present the synthesis of the descriptive statistical analysis for the returns of mutual funds and of the stock exchanges in the three countries in the analyzed period.

Table 5

Returns of mutual funds in Romania, Slovakia and Hungary

\begin{tabular}{|c|c|c|c|c|c|c|c|}
\hline \multirow{2}{*}{\multicolumn{2}{|c|}{ Fund categories }} & \multirow{3}{*}{$\begin{array}{l}\text { Country } \\
\text { Romania }\end{array}$} & \multirow{3}{*}{$\begin{array}{c}\text { Number } \\
\text { of funds } \\
\\
15\end{array}$} & \multicolumn{4}{|c|}{ Distribution moments of returns } \\
\hline & & & & \multirow{2}{*}{$\begin{array}{c}\begin{array}{c}\text { Median of } \\
\text { mean } \\
\text { returns }\end{array} \\
-0.0020\end{array}$} & \multirow{2}{*}{$\begin{array}{c}\begin{array}{c}\text { Median of } \\
\text { standard } \\
\text { deviation of } \\
\text { returns }\end{array} \\
0.0626\end{array}$} & \multirow{2}{*}{$\begin{array}{c}\begin{array}{c}\text { Median of } \\
\text { skewness of } \\
\text { returns }\end{array} \\
-1.2318\end{array}$} & \multirow{2}{*}{$\begin{array}{c}\begin{array}{c}\text { Median of } \\
\text { kurtosis } \\
\text { of returns }\end{array} \\
7.6610\end{array}$} \\
\hline High & \multirow[t]{3}{*}{ Equity funds } & & & & & & \\
\hline \multirow{8}{*}{$\begin{array}{l}\text { risk } \\
\text { funds }\end{array}$} & & Slovakia & 7 & -0.0014 & 0.0554 & -0.9760 & 5.4870 \\
\hline & & Hungary & 126 & -0.00026 & 0.0543 & -0.5930 & 4.0850 \\
\hline & \multirow[t]{3}{*}{ Mixed funds } & Romania & 27 & 0.00029 & 0.0379 & -0.6996 & 7.8513 \\
\hline & & Slovakia & 18 & 0.0011 & 0.0163 & -0.8120 & 5.3130 \\
\hline & & Hungary & 45 & 0.0039 & 0.0218 & -0.5190 & 5.0650 \\
\hline & \multirow[t]{3}{*}{ Other funds } & Romania & 19 & 0.0037 & 0.0142 & -0.4497 & 5.4070 \\
\hline & & Slovakia & 34 & 0.0008 & 0.0117 & -1.3910 & 7.6720 \\
\hline & & Hungary & 125 & 0.0031 & 0.0188 & -0.3030 & 5.4370 \\
\hline \multirow{6}{*}{$\begin{array}{l}\text { Low } \\
\text { risk } \\
\text { funds }\end{array}$} & \multirow[t]{3}{*}{ Bond funds } & Romania & 10 & 0.0057 & 0.0033 & 0.6740 & 4.1953 \\
\hline & & Slovakia & 10 & 0.0014 & 0.0136 & -1.118 & 6.2840 \\
\hline & & Hungary & 52 & 0.0052 & 0.0176 & 0.11900 & 6.2050 \\
\hline & \multirow{3}{*}{$\begin{array}{l}\text { Monetary } \\
\text { funds }\end{array}$} & Romania & 5 & 0.0038 & 0.0029 & -0.0534 & 2.4448 \\
\hline & & Slovakia & 9 & 0.0014 & 0.0013 & 1.0040 & 5.1060 \\
\hline & & Hungary & 46 & 0.0037 & 0.0018 & 0.3140 & 2.8760 \\
\hline
\end{tabular}

Source: Authors' own calculations

As it can be noticed in Table 6 in all three countries the median of the stock exchange indexes were negative indicating low performances of the stock exchanges. This is an expected result, having in mind that the period of analysis included the economic crisis of 2007-2008 and the subsequent years. As it is known and it can be observed in Figure 1 and Table 4 stock exchanges faced crashes in the years 2008 and 2009 in Slovakia and in 2008 in Romania and Hungary, justifying the low performances. The lowest performances at the stock exchange were encountered in Romania. 
Indexes of stock exchanges in Romania, Slovakia and Hungary

(moments of distribution, monthly)

\begin{tabular}{|c|c|c|c|c|c|}
\hline \multirow{2}{*}{ Country } & \multirow{2}{*}{$\begin{array}{c}\text { Stock } \\
\text { index }\end{array}$} & Median of mean & $\begin{array}{c}\text { Median of standard } \\
\text { deviation }\end{array}$ & $\begin{array}{c}\text { Median of } \\
\text { skewness }\end{array}$ & $\begin{array}{c}\text { Median of } \\
\text { kurtosis }\end{array}$ \\
\cline { 3 - 6 } & BET & -0.0072 & 0.0730 & 0.3502 & 2.5381 \\
\hline Romania & SAX & -0.0067 & 0.0350 & -0.0067 & 2.6010 \\
\hline Slovakia & SAX & -0.0018 & 0.0610 & -0.0982 & 2.5556 \\
\hline Hungary & BUX & &
\end{tabular}

Source: Authors' own calculations

At the same time, as a consequence of the evolution of the stock exchanges, the equity funds (as the category of mutual funds comprising a high percentage of shares listed at the stock exchange) was the only fund category that had negative medians of mean returns in all countries, indicating very low performances. However, by comparing stock exchanges with equity funds, it can be noticed that in all three countries the results of the equity funds were better than the results registered by the stock exchanges. This suggests that it was most advantageous for the investors to acquire fund units in equity funds than to acquire shares listed at the stock exchange.

The analysis of the mean returns of the other mutual fund categories reveals that the high risk fund categories (equity funds, other funds and mixed funds) had similar mean returns in all three countries with only the equity funds with a negative median of the mean returns and positive mean returns for the other two fund categories. The low risk funds had the best performances in terms of mean returns in all three countries with the bond funds in Romania and Hungary with the highest median of mean returns for all funds categories.

The fact that the performances of the equity funds are the closest to the stock exchange indexes is normal, given that these funds contain a large proportion of shares traded at the stock exchange. In all countries the spread of the mean returns was the largest for equity funds, illustrating once more that the highest risks are associated with this fund category (Koutsokostas et al., 2019) among all funds categories.

In terms of risks, standard deviation of returns is one of the most used measures of variation (Gravetter \& Wallnau, 2005) that expresses the risks associated to each fund category and to the stock exchange (Jondeau et al., 2000). In Hungary and in Romania, the standard deviations of returns of the stock exchange indexes (BUX and BET) are higher than the standard deviations of returns for all fund categories, indicating the higher risk in investing in the most traded shares at the stock exchange than in investing in mutual funds. In Slovakia, the situation is different, the risk of investing at the stock exchange being lower than the one of investing in equity funds, but higher than the one of investing in any other fund category. In all three countries it is confirmed a higher risk of investing in high risk fund categories (larger standard deviations) than in low risk fund categories. In Romania, Slovakia and Hungary monetary funds had the lowest risk in all fund categories with the lowest standard deviations (0.0029 in Romania; 0.0013 in Slovakia and 0.0018 in Hungary).

A more detailed analysis of the risk is conducted by looking further at skewness and kurtosis coefficients. Investors prefer to invest in shares and in mutual funds that have positive skewness coefficients, that frequently have small losses and few extreme gains (De Richard et al., 2015). Only in Romania, the skewness of the BET index was positive, while in Hungary and Slovakia this was negative indicating high risks to obtain extreme negative values (losses). As far as the mutual funds are concerned, only low risk funds (bond funds in Romania, monetary funds in Slovakia and both bond and monetary funds in Hungary) had positive skewness coefficients indicating a probability of positive extreme values 
(gains). On overall, it can be appreciated that the best risk related results (lower risks of extreme negative values) are encountered in Hungary, where the negative values of the skewness coefficients were the smallest and both low risk fund categories had positive skewness coefficients. The present study reached similar results with other studies conducted in emerging financial markets where equity funds have higher levels of asymmetry in comparison with bond funds (Bekaert et al., 1998; Erb et al., 1999), being riskier where the asymmetries are negative.

The analysis of the kurtosis coefficients illustrated that stock exchange indexes do not confirm the high risks to have numerous extreme values, but the stock exchange indexes had low returns on overall anyhow. By comparison, mutual funds that have high values of the kurtosis (over 3), illustrating high risks to have extreme values. According to the kurtosis coefficients the highest risks of having extreme values is encountered for equity funds and mixed funds in Romania and other funds in Slovakia (values higher than 7). The lowest risks of having extreme values was present for monetary funds in Romania and Hungary (values under 3).

The similarity in the three countries is that in all three, the monetary funds had the lowest risk of having extreme values in the analyzed period. as monetary funds are an investment alternative in periods of economic crisis. as being safer than other fund categories and at the same time having better returns than the bank deposits (Diaconașu \& Asăvoaiei, 2011, p. 52).

Considering that the analyzed period also comprised the period of economic crisis (2007-2009), it can be explained why the investment risk was high for the majority of the mutual fund and for the stock exchange investment. Similarly, Firdrmuc et al. (2013, p. 18) illustrates for Slovakia that in the crisis period the risks associated to bonds (that by definition are low risk assets) increased due to the increase in their spreads. The results also correspond to the opinions expressed by Cevik et al. (2016) that point out the effect of the economic crisis on the returns of the stock exchanges from Central and Eastern Europe, where the investment risk increased.

\section{CONCLUSION}

The statistical analyses illustrate that there are both similarities and differences in the performance risk relationship for mutual funds and stock exchanges between the three countries for the analyzed period.

Firstly, the investment in shares traded at the stock exchanges is less performant than the investment in mutual funds for all fund categories, except the equity funds in Slovakia. At the same time, investment in shares listed at the stock exchange is riskier than the investment in mutual funds. re-confirming what also others found in their researches (Frahm \& Huber, 2019). In all three countries, the national stock exchange indexes (BET, SAX and BUX) had medians of mean returns smaller than those of mutual funds, indicating on overall lower returns and higher risks of the investments in shares quoted at the national stock exchanges, than in mutual funds. These results are consistent with conclusions of other authors (Bakker \& Gross, 2004; Filip, 2018) according to which the investment portfolio diversification (Kaur \& Kaushik, 2015) and collective investments diminish the risks (Chovancova \& Zofcak, 2012). The use of mutual funds as a way of improving the investment management (Filip, 2018) leads to better investment results, as collective investments ensures a better administration of the risk and the application of specific techniques for portfolio management that can distribute the risks across different parts of the financial system (Baker \& Gross, 2004).

Secondly, equity funds are the fund category with the highest risk in all fund categories in all three countries, illustrated by both skewness and kurtosis coefficients. These come to complete the literature that states that equity funds as high risk funds usually have leptokurtik distributions (kurtosis coefficients 
higher than 3) (Jondeau et al., 2000; De Richard et al., 2015) and that the equity returns especially have negative asymmetries (Jondeau et al., 2000, p. 14). These findings are amplified by the period of study characterized also by economic turmoil, being well known the fact that crisis periods multiply the investment risks (Koutsokostas et al., 2019; Salganik-Shoshan, 2017).

Thirdly, in all three countries the low risk funds (bonds and monetary funds) had better performances in terms of both returns and risks than the high risk funds, confirming the conclusions of other studies that low risk funds perform better in economic recession periods than in economic expansion periods (Kosowski, 2011; Salganik-Shoshan, 2017).

The present study contributes and improves the existing knowledge by offering evidence from young and developing financial markets (that usually are less studied on the example of three selected case studies from Central and Eastern Europe. Another contribution of the study stands in the inclusion of all five mutual fund categories prevalent in the studied period (as opposed to usually the inclusion of just one mutual fund category - equity funds or bond funds) for the comparison with the stock exchanges. The present research will be further developed by extending it to a larger period of time, as well as to a larger number of countries in Central and Eastern Europe, so that to have a more comprehensive image about the region and the fluctuations of its capital markets in time.

\section{REFERENCES}

Albu, L.L., Lupu, R. \& Cantemir, C. (2014). A nonlinear model to estimate the long term correlation between market capitalization and GDP per capita in Eastern EU countries, Working paper no. 141115, Institute for Economic Forecasting. Retrieved November, 7, 2019, from https://ideas.repec.org/p/rjr/wpiecf

Ajaz Khan, K., Çera, G., Nétek, V. (2019). Perception of the selected business environment aspects by service firms. Journal of Tourism and Services, 10(19), 111-127. https://doi.org/10.29036/jots.v10i19.115

Andrei T. \& Bourbonnais R. (2017). Econometrie. București: Economică.

Androniceanu A., Sabie O. M. \& Pegulescu A. (2020, February). An integrated approach of the human resources motivation and the quality of health services. Theoretical and Empirical Research in Urban Management, 15(1), 4253.

Androniceanu A., Gherghina R. \& Ciobănașu M. (2019). The interdependence between fiscal public policies and tax evasion. Administrație și Management Public, 32, 32-41, doi: 10.24818/amp/2019.32-03.

Authority for Financial Monitoring (2019). Annual Reports. Retrieved March, 6, 2020, from: https://asfromania.ro/en/publications/annual-report/asf-annual-report

Bajus, R. \& Stasova, L. (2015). Trading with bonds in capital markets within V4 Countries. Central European Conference in Finance and Economics, CEFE 2015, 29-35, Herlany, Slovakia.

Bakker, M.R. \& Gross, A. (2004). Development of non-bank financial institutions and capital markets in European Union accession countries. $\quad$ Retrieved January, $\quad 14, \quad$ from http://documents.worldbank.org/curated/en/889731468779109396/Development-of-non-bank financial institutions-and-capital-markets-in-European-union-accession-count.

BAMOSZ, The Fund Managers' Association from Hungary. Retrieved January, 11, 2020, from http://www.bamosz.hu/

Barunik, J. \& Vacha, L. (2013). Contagion among Central and Eastern European Stock Markets during the Financial Crisis. Czech Journal of Economics and Finance, 63(5), 443-453.

Batsaikhan, U. \& Demertzis, M. (2018). Financial literacy and inclusive growth in the European Union. Policy Contribution, 8, Bruegel, European Commission. Retrieved November, 17, 2019, from https://bruegel.org/wp-content/uploads/2018/05/PC-08 2018.pdf.

Beckmann, E. (2013). Financial Literacy and Household Savings in Romania. Numeracy, 6 (2), Article 9. Retrieved December 14, 2019, from http://scholarcommons.usf.edu/numeracy/vol6/iss2/art9.

Beckmann, E. (2013). Financial literacy and household savings in Romania. Numeracy, 6(2), Article 9. doi: http://dx.doi.org/10.5038/1936-4660.6.2.9 
Bekaert, G., Erb, C.B., Harvey, C.R. \& Viskanta, T.E. (1998). Distributional characteristics of emerging markets returns and asset allocation. Journal of Portfolio Management, 24(2), 102-116.

Bekaert G. \& Harvey C.R. (2003). Emerging markets finance. Journal of Empirical Finance, 10, 3-55.

Bilan, Y., Gavurova, B., Stanisław, G., \& Tkacova, A. (2017). The Composite Coincident Indicator (CCI) for Business Cycles. Acta Polytechnica Hungarica, 14(7), 71-90.

BET index. Financial Instruments. Retrieved December, 15, 2019, from http://www.bvb.ro/Financial Instruments/Indices/Overview.

Brokesova, Z., Cupak, A. \& Kolev, G. (2017). Financial literacy and voluntary savings for retirement in Slovakia. Working Paper no.10/2017, National Bank of Slovakia. Retrieved, December, 10, 2019, from https://w ww.nbs.sk/_img/Documents/PUBLIK/WP_10_2017_Cupak_Financial_Literacy_EN.pdf.

Brooks, C. (2002). Introductory econometrics and finance. Cambridge: Cambridge University Press.

BSSEb. Bratislava Stock Exchange. Factbook (1999-2018). Retrieved December 20, 2019, from http://www.bsse.sk/bcpben/Statistics/Year/tabid/171/language/en-US/Default.aspx

Bukowski, S.I. (2014). Development of equity market and its significance in the Slovak economy. Central European Review of Economics and Finance, 4(1), 5-20.

BUX index. Retrieved December, 15, 2019, from https://www.bse.hu/Products-and-Services/Indices/BUX.

Cepel, M., Kljucnikov, A., Kozubikova, L., \& Krajcik, V. (2019). Local Currency as a Mean of Regional Competitiveness Development. Journal of Competitiveness, 11(4), 22-39. https://doi.org/10.7441/joc.2019.04.02

Cevik, N.K., Dibooglu, S. \& Kutan, A.M. (2016). Real and financial sector studies in Central and Eastern Europe: a review. Czech Journal of Economics and Finance, 66(1), 2-31.

Chehabeddine, M., Tvaronavičiene, M. 2020. Securing regional development. Insights into Regional Development, 2(1), 430-442. http://doi.org/10.9770/IRD.2020.2.1(3)

Chen, Y. \& Qin, N., (2017, May). The behavior of investor flows in corporate bond mutual funds. Management Science, 63(5), 1365-1381.doi: http://dx.doi.org/10.2139/ssrn. 2022059

Chovancova, B. \& Zofcak, S. (2012). Collective Investment. Bratislava: Walter Kluwer.â

Chovancova, B., Hudcovsky, J., \& Kotaskova, A. (2019). The Impact of Stocks and Bonds on Pension Fund Performance. Journal of Competitiveness, 11(2), 22-35. https://doi.org/10.7441/joc.2019.02.02

Christoffersen, P.F. (2015). Elements of Financial Risk Management, $2^{\text {nd }}$ edition, Academic Press, Elsevier.

Darabos, É. (2016). Particularity of local taxation in Hungary. Acta Oeconomica Universitatis Selye, 5 (1), 29-39.

Deltuvaite, V. (2016). Transmission of shocks through stock markets channel: the case of the CEECs. Procedia Economics and Finance, 39, 292-297.

DeRichard, A., DeFusco, D., McLeavey, W., Pinto, D., Runkle, E., Mark, J. \& Anson, P. (2015). Quantitative Investment Analysis, $3^{\text {rd }}$ edition, John Wiley and Sons.

Diaconașu, D. E. \& Asăvoaiei, A. (2011). The role of investment funds in Romania. The Romanian Economic Journal, XIV (39), 45-59.

Dragotă, I.M., Tatu-Cornea, D. \& Tulbure N. (2016). Determinants of development of the mutual fund industry: a socio-cultural approach. Prague Economic Papers, 25(4), 476-493.

Erb, C.B., Harvey, C.R. \& Viskanta, T.E. (1999, Winter). New perpectives on emerging market bonds. Journal of Portfolio Management, 25, 83-92.

European Fund and Asset Management Association (2019). Financial Markets. Retrived March, 6, 2020, from https://www.efama.org/Lists/Themes/form/DispItem.aspx ?ID=4

Filip, D. (2011). Performance persistence of equity funds in Hungary. Contemporary Economics, 5(1), 18-34.

Filip, D. (2014). Survivor bias and performance of mutual funds in Hungary. Periodica Polytechnica - Social and Management Sciences, 22(1), 47-56.

Filip, D. (2017a). Mutual funds: Does the performance erosion effect exist? Evidence from Czech Republic, Hungary and Poland. Finance a uver - Checz. Journal of Economics and Finance, 67(6), 512-538.

Filip, D. (2017b). The return variability and dispersion: evidence from mutual funds in post-transition countries. Retrieved October, 12, 2019 from https://www.researchgate.net/ publication/316338861

Filip, D. (2018). The impact of fund attributes on performance: Empirical evidence for Polish equity funds. Zb.rad. Ekon.fak. Rij, 36(2), 465-488. 
Fidrmuc, J., Klein, C., Price, R. \& Worgotter, A. (2013, February). Slovakia: a catching up Euro area member in and out of the crisis. Policy Papers no. 55. IZA Policy Papers Series. Retrieved October 19, 2019 from https://www.oecd-ilibrary.org/economics/slovakia-a-catching-up-euro-area-member-in-and-out-of-thecrisis_5k4c9ktpf47g-en.

Frahm G. \& Huber F. (2019). The outperformance probability of mutual funds. Journal of Risk and Financial Management, 12, 108, doi: 10.3390/jrfm12030108

Fund Managers' Association from Romania (2019). All Financial Investment Companies \& Fondul Proprietatea. Retrieved January 15, 2020 from http://www.aaf.ro/en/sif-uri/

García-Machado, J.J. (2018). The latest streams in finance research: an updated bibliometric mapping based on cooccurrence data, Forum Scientiae Oeconomia, 6(3), 7-23. doi: 10.23762/FSO_VOL6_NO3_1

Gavurova, B., Tkacova, A. \& Tucek, D. (2017). Determinants of public fund's savings formation via public procurement process. Administratie si Management Public, 28, 25-44.

Gravetter, F.J. \& Wallnau, L.B. (2005). Essentials of Statistics for the Behavioral Sciences, $6^{\text {th }}$ edition, Thomson Wadsworth.

Hilkevics, S., Hilkevica, G. 2017. New information technologies use for Latvian stock companies financial health evaluation. Entrepreneurship and Sustainability Issues, 5(2), 178-189 http://doi.org/10.9770/jesi.2017.5.2(1)

Horobeț, A.L. \& Belașcu, L. (2015). The behaviour of Central and East European stock markets during high volatility episodes. The $9^{\text {th }}$ International Days of Statistics and Economics, Prague, September 10-12. Retrieved June, 26, 2019 from https://msed.vse. cz/msed 2015/article/162-Horobet-Alexandra-paper.pdf.

Hudáková, J. Fil’a, M., Maroš, M. (2017). Innovation potential of the regions in the Slovak republic. Acta Oeconomica Universitatis Selye, 6 (2), 81- 88.

Investment Company Institute (2019). 2019 Investment Company Fact Book. Retrieved March, 7, 2020, from: https://www.icifactbook.org/data/

Jaba, E., Mironiuc, M., Roman, M., Robu, I.B. \& Robu, M.A. (2013). The statistical assessment of an emerging capital market using the panel data analysis of the financial information. Economic Computation and Economic Cybernetics Studies and Research, 1(2), 21-36.

Jondeau, E., Poon, S.H. \& Rockinger, M. (2000). Financial modelling under Non-Gaussiaqn Distributions, London: Springer Verlag.

Kaluge, D. (2019) Multifactor on macroeconomic fundamentals to explain the behavior of sectoral indices in the Indonesian stock exchange. Entrepreneurship and Sustainability Issues, 7(1), 44-51. http://doi.org/10.9770/jesi.2019.7.1(4)

Kaur, I. \& Kaushik, K.P. (2015). Determinants of investment behaviour of investors towards mutual funds. Journal of Indian Business Research, 8(1), 19-42.

Kinnunen, J., Androniceanu, A, Georgescu, I. (2019). The role of economic and political features in classification of countries in-transition by Human Development Index. Informatica Economică, 23(4), 26-40.

Ključnikov, A., Civelek, M., Čech, P. \& Kloudová, J. (2019). Entrepreneurial orientation of SMEs' executives in the comparative perspective for Czechia and Turkey. Oeconomia Copernicana, 10(4), 773-795. doi: 10.24136/oc.2019.035

Kosowski, R. (2011). Do mutual funds perform when it matters most to investors? US mutual fund performance and risk in recessions and expansion. The Quarterly Journal of Finance, 1(3), 607-664.

Koutsokostas, D., Papathanasiou, S. \& Balios, D. (2019). Adjusting for risk factors in mutual fund performance and performance persistence - Evidence from the Greek market during the debt crisis. Journal of Risk. Finance, 20(4), 352-369.

Lemeshko, O. \& Rejnus, O. (2015). Modeling the size of the mutual fund industry in countries of Central and Eastern Europe. Financial Assets and Investing, 6(1), 1-28.

Li, Ma. (2013). Mutual fund flows and performance: a survey of empirical findings. Retrieved 14 December, 2016 https://www.wiwi.hu-berlin.de/de/professuren/bwl/cofi/ research /workingpapers/li-fundflowperformance-2013.pdf.

Lusardi, A. (2019). Financial literacy and the need for financial education: evidence and implications. Swiss Journal of Economics and Statistics, 155, 1-12, doi:10.1186/s41937-019-0027-5. 
Masood, O., Tvaronavičienė, M., Javaria, K. (2019). Impact of oil prices on stock return: evidence from G7 countries. Insights into Regional Development, 1(2), 129-137. https://doi.org/10.9770/ird.2019.1.2(4)

Mesagan, E.P., Ogbuji, I.A., Alimi, Y.O., Odeleye, A.T. (2019). Growth effects of financial market instruments: The Ghanaian experience, Forum Scientiae Oeconomia, 7(4), 67-82. doi: 10.23762/FSO_VOL7_NO4_5

Mura, L., Buleca, J. (2012). Evaluation of financing possibilities of small and medium industrial enterprises. Procedia Economics and Finance, 3, 217 - 222.

Nadirov, O., Aliyev, K., Dehning B. (2017). To work more or iess? The Impact of taxes and life satisfaction on the motivation to work in Continental and Eastern Europe. Economics and Sociology, 10(3), 266-280. doi:10.14254/2071-789X.2017/10-3/19

Phillips, B., Pukthuanthong, K. \& Rau, P.R. (2016). Past performance may be an illusion: performance, flows, and fees in mutual funds. Critical Finance Review, 5(2), 351-398.

Poór, J., Juhász, T., Machová, R., Bencsik, A., \& Bilan, S. (2018). Knowledge management in human resource management: foreign-owned subsidiaries' practices in four CEE countries. Journal of International Studies, 11(3), 295-308. doi:10.14254/2071-8330.2018/11-3/23

Prats, M.A. \& Sandoval, B. (2016). Stock Market and Economic Growth in Eastern Europe. Economics Discussion Papers, No.35, Kiel Institute for the World Economy. Retrieved June 26, 2019 from http://www.economicsejournal.org/economics/discussionpap ers/201

Rachev, S.T., Mittnik, S., Faboyyi, F.J., Focardi, S. M. \& Jasic, T. (2007). Financial Econometrics. New York: John Wiley\&Sons.

Raišienè, A. G., Bilan, S., Smalskys, V., Gečienè, J. (2019). Emerging changes in attitudes to inter-institutional collaboration: the case of organizations providing social services in communities. Administratie si Management Public, 33, 34-56, doi:10.24818/amp/2019.33-03.

Rajnoha, R., Lorincová, S. (2015). Strategic management of business performance based on innovations and information support in specific conditions of Slovakia. Journal of Competitiveness, 7(1), 3-21. doi: 10.7441/joc.2015.01.01

Ruppert, D. \& Matteson, D.S, (2015) Statistics and Data Analysis for Financial Engineering, 2nd edition, New York: Springer.

Salganik-Shoshan, G. (2017). Business cycle and investment flows of retail and institutional mutual funds, International Journal of Managerial Finance, 13(5), 498-520.

SASS, The Fund Managers' Association from Slovakia. Retrieved December 13, 2019, from http://www.ass.sk/

SAX index. Retrieved December 15, 2019, from https://tradingeconomics.com/slovakia/stock-market.

Simionescu, M. (2016). Competitiveness and economic growth in Romanian regions. Journal of Competitiveness, 8(4), 46 - 60. doi: 10.7441/joc.2016.04.03

Sindelar, J. \& Budinski, P. (2019). Does commission remuneration affect the investor's outcome? Experience from Central and Eastern Europe. Journal of Financial Regulation and Compliance, 27(4), 1358-1988.

Sirri, E. \& Tufano, P. (1998). Costly search and mutual funds flows. Journal of Finance, 53(5), 1589-1622.

Stoltz O. (2020). The equity curve and its relation to future stock returns. Journal of Risk and Financial Management, 13(19). doi:10.3390/jrfm13020019.

Swiecka B., Yesildag E., Özen E. \& Grima S. (2020). Financial Literacy: The Case of Poland. Sustainability, $12,700$. doi:10.3390/su12020700.

Tsay, R.S. (2010). Financial Time Series and Their Characteristics, 3rd edition, New York: John Wiley \& Sons.

Tudorache, F.G., Nicolescu, L. \& Lupu, R. (2015). Evolution of mutual funds in Romania: performances and risks. Romanian Journal of Economic Forecasting, 18(4), 180-197.

Tung, L. T. (2018). The Effect of Fiscal Deficit on Economic Growth in an Emerging Economy: Evidence from Vietnam. Journal of International Studies, 11(3), 191-203. doi:10.14254/2071-8330.2018/11-3/16

Tvaronaviciene M. (2019). Insights into global trends of capital flows' peculiarities: emerging leadership of China. Administrație și Management Public, 32, 6-17. doi: 10.24818/amp/2019.32-01.

Urdan, T.C. (2011). Statistics in Plain English, $3^{\text {rd }}$ edition, New York: Routledge.

Vychytilova, J. (2018). Stock market development beyond the GFC: the case of V4 countries. Journal of Competitiveness, 10(2), 149-163. doi:10.7441/joc.2018.02.10. 